\title{
Silencing of Phytopathogen Communication by the Halotolerant PGPR Staphylococcus Equorum Strain EN21
}

\author{
Clara Vega ${ }^{1,2}$, Miguel Rodríguez ${ }^{1,2}$, Inmaculada Llamas ${ }^{1,2, *}$, Victoria Béjar ${ }^{1,2}$ and \\ Inmaculada Sampedro $1,2, *$ D \\ 1 Department of Microbiology, Faculty of Pharmacy, University of Granada, 18071 Granada, Spain; \\ cvegazayas@gmail.com (C.V.); miguelrg@correo.ugr.es (M.R.); vbejar@ugr.es (V.B.) \\ 2 Institute of Biotechnology, Biomedical Research Center (CIBM), University of Granada, 18100 Granada, Spain \\ * Correspondence: illamas@ugr.es (I.L.); isampedro@ugr.es (I.S.)
}

Received: 10 December 2019; Accepted: 22 December 2019; Published: 24 December 2019

\begin{abstract}
Increasing world food demand together with soil erosion and indiscriminate use of chemical fertilization highlight the need to adopt sustainable crop production strategies. In this context, a combination of plant growth-promoting rhizobacteria (PGPR) and pathogen management represents a sustainable and efficient alternative. Though little studied, halophilic and halotolerant PGPR could be a beneficial plant growth promotion strategy for saline and non-saline soils. The virulence of many bacterial phytopathogens is regulated by quorum sensing (QS) systems. Quorum quenching (QQ) involves the enzymatic degradation of phytopathogen-generated signal molecules, mainly $\mathrm{N}$-acyl homoserine lactones (AHLs). In this study, we investigate plant growth-promoting (PGP) activity and the capacity of the halotolerant bacterium Staphylococcus equorum strain EN21 to attenuate phytopathogens virulence through QQ. We used biopriming and in vivo tomato plant experiments to analyse the PGP activity of strain EN21. AHL inactivation was observed to reduce Pseudomonas syringae pv. tomato infections in tomato and Arabidopsis plants. Our study of Dickeya solani, Pectobacterium carotovorum subsp. carotovorum and Erwinia amylovora bacteria in potato tubers, carrots and pears, respectively, also demonstrated the effectiveness of QS interruption by EN21. Overall, this study highlights the potential of strain S. equorum EN21 in plant growth promotion and QQ-driven bacterial phytopathogen biocontrol.
\end{abstract}

Keywords: Staphylococcus equorum strain EN21; halotolerant bacterium; bacterial phytopathogen; PGPR; quorum sensing; quorum quenching; communication silencing

\section{Introduction}

In recent years, the growing food demand worldwide has highlighted the need for sustainable crop production. The principal causes of food scarcity include biotic and abiotic stress conditions such as salinity, drought and plant pathogens [1]. Crop quality and yields are also affected by global climate change, while the shortfall in global agricultural output with regard to the demand for food is alarming (www.fao.org/economic/esa).

Indiscriminate use of chemical fertilizers and antibiotics in traditional agriculture has become a significant cause of soil and water pollution and other environmental problems [2]. In this context, new strategies, including plant growth promotion and pathogen management techniques to optimise productivity and crop quality, are crucial. Plant growth-promoting rhizobacteria (PGPR) have also been widely recognised as important tools for maintaining root health and nutrient uptake [3].

Though poorly studied, halophilic and halotolerant PGPR could be effectively used as part of a plant growth promotion strategy for saline and non-saline soils. These bacteria, whose multiple 
mechanisms are involved in producing enzymes such as 1-aminocyclopropane-1-carboxylic acid (ACC) deaminase, auxins, exopolysaccharides and siderophores, play an important role in boosting plant growth under stress conditions including salinity [4].

The virulence and associated functions of many bacterial phytopathogens, which cause major economic losses, are regulated by quorum sensing (QS) systems. One promising strategy, involving quorum quenching (QQ), to combat infections is based on the enzymatic degradation of signal molecules [5]. QS is used by a wide variety of bacteria to regulate gene expression in a cell density-dependent manner [6-8]. This mechanism involves the production, release and recognition of the accumulation of signalling molecules known as autoinducers [9]. The best-studied autoinducers are $\mathrm{N}$-acyl homoserine lactones (AHLs) which are produced by many Proteobacteria. Diffusible signal factors (DSFs) and quinolones, which have been identified in Pseudomonas aeruginosa [10] and Xanthomonas spp. [11], are also autoinducers. QS plays an important role in the regulation of bacterial functions including virulence gene expression, biofilm formation and antibiotic resistance [6,12-15]. In plant pathogenic bacteria such as Pseudomonas syringae pv. syringae [12], Pectobacterium carotovorum [16] and Agrobacterium tumefaciens [17], QS has been reported to regulate cell wall-degrading enzyme production, cellular motility and biofilm formation. Given the contribution of these QS-coordinated virulence factors to the pathogenesis of phytopathogens [14], quorum sensing signal degradation could be an effective phytopathogen biocontrol strategy.

QQ involves AHL-degrading enzymes such as lactonase, acylase and oxidorreductase [18], which have been identified in bacterial species including Bacillus spp. [19], Pseudomonas spp. [20] and Rhodococcus spp. [21]. However, little is known about the role played by bacterial signalling communication in pathogen management.

Results regarding the reduction of virulence in bacterial plant pathogens, especially with respect to Pectobacterium carotovorum-potato soft rot, have been promising [22-25]. We selected halotolerant strain Staphylococcus sp. EN21, previously isolated from the halophyte Salicornia hispanica, for its in vitro plant growth-promoting properties and its efficient degradation of C10-HSL. We aimed to analyse PGP activity and the ability to attenuate the virulence of phytopathogenic bacteria by QQ of EN21. The study provides information on the PGP activity of this strain which was evaluated with the aid of biopriming assays and in vivo experiments with tomato plants. QQ activity was tested in synthetic AHLs and crude AHL extracts from bacterial phytophatogens. Overall, we describe a beneficial strategy to regulate plant bacterial infections in different hosts involving a combination of plant growth promotion and pathogen communication silencing.

\section{Experimental Procedures}

\subsection{Bacterial Strains, Media, Compounds and Culture Conditions}

The strain Staphylococcus sp. EN21 selected for this study was previously isolated from the rhizosphere of the Salicornia hispanica plant taken from El Saladar del Margen (Cúllar, Granada; $37^{\circ}$ $38^{\prime} 43.6^{\prime \prime} \mathrm{N}, 2^{\circ} 35^{\prime} 59.0^{\prime \prime} \mathrm{W}$ ). The following plant bacterial pathogens were used-Agrobacterium fabrum C58 ATCC $33970^{\mathrm{T}}$, Dickeya dianthicola DSM $18054^{\mathrm{T}}$, D. solani IPO $2222^{\mathrm{T}}$, Erwinia amylovora CECT $222^{\mathrm{T}}$, Pectobacterium atrosepticum CECT $314^{\mathrm{T}}$, P. carotovorum subsp. carotovorum CECT $225^{\mathrm{T}}$, Pseudomonas syringae pv. syringae LMG $1247^{\mathrm{T}}$ and P. syringae pv. tomato DC3000.

Strain EN21 and the phytophatogens were grown in trypticase soy broth (TSB) medium. The biosensor strains Chromobacterium violaceum CV026 [26] and C. violaceum VIR07 [27] were cultured in Luria-Bertani (LB) medium, while Agrobacterium tumefaciens NTL4 (pZLR4) was grown in Agrobacterium broth (AB) medium [28]. Malt Extract Yeast Extract (MY) medium [29], supplemented with a sea-salt solution [30] containing $5 \%(w / v) ~ N a C l$, was used for selective plate counts. All strains were grown during $16 \mathrm{~h}$ at $28^{\circ} \mathrm{C}$ and $100 \mathrm{rpm}$ on a rotary shaker unless otherwise stated. When needed, antibiotics were used in final concentrations of $50 \mu \mathrm{g} \mathrm{mL}{ }^{-1}$ kanamycin $(\mathrm{Km})$ and $50 \mu \mathrm{g} \mathrm{mL} \mathrm{L}^{-1}$ gentamicin $(\mathrm{Gm})$. 
The following synthetic AHLs (Sigma ${ }^{\circledR}$ ) were used-C4-HSL (N-butyryl-DL-homoserine lactone), C6-HSL (N-hexanoyl-DL-homoserine lactone), 3-O-C6-HSL (N-3-oxo-hexanoyl-DL-homoserine lactone), C8-HSL (N-octanoyl-DL-homoserine lactone), 3-O-C8-HSL (N-3-oxo-octanoyl-DL-homoserine lactone), C10-HSL ( $N$-decanoyl-DL-homoserine lactone), 3-OH-C10-HSL (N-3-hydroxydecanoyl-DL-homoserine lactone), $\mathrm{C}_{12}$-HSL (N-dodecanoyl-DL-homoserine lactone) and 3-O-C12-HSL (N-3-oxo-dodecanoyl-DLhomoserine lactone).

\subsection{Characterization of Strain EN21}

Optimal growth and salt stress tolerance of EN21 were tested in Tryptic Soy Broth (TSB) medium supplemented with $0-25 \%(w / v) \mathrm{NaCl}$. Other phenotypic characteristic were evaluated-acid and alkaline phosphatase [31,32]; hydrolysis of starch and casein [33], cellulose [34], chitin [35], DNA [36], Tween ${ }^{\circledR} 20$, Tween ${ }^{\circledR} 80$ and gelatin [33] and siderophore production [37]. EN21 toxicity was assessed using the Microtox ${ }^{\circledR}$ rapid test system (Environmental Bio-Detection Products Inc., Mississauga, ON, Canada) [38].

Genomic DNA was isolated from strain EN21 using the X-DNA purification kit (Xtrem Biotech S.L., Granada, Spain). The 16S rRNA gene was amplified with the aid of universal bacterial primers 16F27 and 16R1488 and the PCR product was then purified and cloned into the pGEM ${ }^{\circledR}$-T vector (Promega, Fitchburg, WI, USA). Using BLASTN software [39], the DNA sequence obtained was compared to reference 16S rRNA gene sequences in the GenBank and EMBL databases and pairwise 16S rRNA gene sequence similarity was calculated using the EzBioCloud server [40].

\subsection{Plant Growth-Promoting Assays}

The PGP traits of strain EN21 were tested in tomato (Solanum lycopersicum L.) seeds and seedlings for biopriming and growth-promoting assays, respectively. In both cases, tomato seeds were surface-sterilised with $2.5 \%(w / v)$ sodium hypochlorite for $15 \mathrm{~min}$, followed by $7 \%(v / v)$ hydrogen peroxide for $15 \mathrm{~min}$. Seeds were washed four times in sterile distilled water and left to imbibe for $90 \mathrm{~min}$ in sterile distilled water. For biopriming, sterilised seeds were incubated with a $10^{9} \mathrm{CFU}$ $\mathrm{mL}^{-1}$ suspension of strain EN21 cells in water for 1 hour at $28^{\circ} \mathrm{C}$ and $120 \mathrm{rpm}$, with sterile distilled water used as control. Thirty bacterised seeds were placed on each petri dish containing $5 \mathrm{~mL}$ sterile distilled water-soaked paper and then incubated for 4 days at $28{ }^{\circ} \mathrm{C}$ in darkness. Three replicates were performed per treatment. The effects of biopriming were evaluated using the vigour index (VI) [41]. For the plant growth promotion assay, 10 sterilised seeds were sown in individual pots containing sterilised vermiculite ( 3 cycles at $121^{\circ} \mathrm{C}$ and at $1 \mathrm{~atm}$ for $20 \mathrm{~min}$ ). Each pot was irrigated with $250 \mu \mathrm{L}$ of $10^{9} \mathrm{CFU} \mathrm{mL}{ }^{-1}$ suspension and $250 \mu \mathrm{L}$ of sterile distilled water (control) weekly for 3 weeks. Pots were kept in an indoor greenhouse during a long-day photoperiod (16:8 h light:dark) at $25{ }^{\circ} \mathrm{C}$ for 4 weeks. The plants were then harvested and the aerial and radicular parts were measured and oven-dried at $40{ }^{\circ} \mathrm{C}$ for $48 \mathrm{~h}$ for subsequent dry weight determination.

\subsection{Quorum Quenching Activity Against Synthetic AHLs and Crude AHL Extracts From Plant Bacterial Pathogens}

QQ activity of Staphylococcus sp. strain EN21 for AHL degradation was analysed using a well diffusion agar-plate assay [42,43]. Briefly, each synthetic AHL in a final concentration of $25 \mu \mathrm{M}$ was added to overnight cultures of strain EN21 and then incubated at $28{ }^{\circ} \mathrm{C}$ for $24 \mathrm{~h}$. Cell-free TSB medium supplemented with the same concentration of AHLs was incubated as negative control. The remaining AHLs were detected on LB agar plates overlaid with C. violaceum CV026 to detect shortand medium-chain AHLs, with C. violaceum VIR07 to detect C10-HSL and 3-OH-C10-HSL and on AB agar plates supplemented with $80 \mathrm{\mu g} \mathrm{mL}^{-1}$ of 5-bromo-4-chloro-3-indolyl-B-D-galactopyranoside (X-gal) overlaid with $A$. tumefaciens NTL4 (pZRL 4) to detect medium- and long-chain AHLs. After incubation, AHL production was checked for the appearance of a purple or blue colour around each well. 
To determine QQ activity against AHLs produced by phytopathogens, crude AHL extracts from Agrobacterium fabrum C58 ATCC $33970^{\mathrm{T}}$, Dickeya dianthicola DSM $18054^{\mathrm{T}}$, D. solani IPO $2222^{\mathrm{T}}$, Erwinia amylovora CECT $222^{\mathrm{T}}$, Pectobacterium atrosepticum CECT $314^{\mathrm{T}}$, P. carotovorum subsp. carotovorum CECT $225^{\mathrm{T}}$, Pseudomonas syringae pv. syringae LMG $1247^{\mathrm{T}}$ and P. syringae pv. tomato DC 3000 were collected as described elsewhere $[25,44,45]$. Briefly, AHLs from an overnight culture of each bacterium were extracted twice with dichloromethane (1:1), then dried and re-suspended in $15 \mu \mathrm{L}$ of $70 \%(v / v)$ methanol. A crude AHL extract from each pathogen $(5 \mu \mathrm{L})$ was added to $5 \mathrm{~mL}$ of an overnight EN21 culture in LB medium. A similar quantity of each crude extract was added to $5 \mathrm{~mL}$ cell-free TSB medium for use as control. After incubation at $28^{\circ} \mathrm{C}$ for $24 \mathrm{~h}$ at $150 \mathrm{rpm}$, the remaining AHLs were extracted as described above and $20 \mu \mathrm{L}$ of each sample was spotted on sterile paper disks ( $5 \mathrm{~mm}$ in diameter), placed on $\mathrm{AB}$ agar plates and detected using biosensor A. tumefaciens NTL4 (pZLR4).

\subsection{Competitive Assay}

The antagonistic activity of strain EN21 from the plant bacterial pathogens used in this study was evaluated according to the well diffusion method [46]. An overlay of each pathogen was prepared on LB agar plates and 100- $\mu \mathrm{L}$ aliquots of the supernatant from a 5-day culture of strain EN21 was placed in the wells previously done. After $48 \mathrm{~h}$ of incubation at $28^{\circ} \mathrm{C}$, plates were examined for growth inhibition halos surrounding the wells.

\subsection{Phytopathogens QS System Interference by Co-Culture Assays}

Co-culture assays of plant bacterial pathogens and strain EN21 were carried out according to the methodology described by Torres et al. [43]. Briefly, $10^{9} \mathrm{CFU} \mathrm{mL} \mathrm{m}^{-1}$ of each pathogenic strain was co-cultured with $10^{9} \mathrm{CFU} \mathrm{mL} \mathrm{mL}^{-1}$ of strain EN21 (1:100) in TSB medium at $28^{\circ} \mathrm{C}$ and $150 \mathrm{rpm}$ for $24 \mathrm{~h}$. A similar concentration of each pathogen was added to cell-free TSB medium as negative control. The remaining AHLs from each co-culture were extracted as described above and, using the well diffusion agar method, were detected on $A B$ agar plates supplemented with $X$-gal and overlaid with biosensor $A$. tumefaciens NTL4 (pZRL4). The abundance of each bacterium was determined in mono- and co-cultures by serial dilution and plate counts using Tryptic Soy Agar (TSA) plates in which colony morphology was used to determine inter-species differences. In the case of similar colony patterns, double plate counts were performed using TSA plates and MY agar plates with a $5 \%(w / v)$ $\mathrm{NaCl}$ solution as selective medium for strain EN21. To analyse the impact of AHL degradation in the QS system of the phytopathogens, virulence and phenotypic traits were evaluate as described above.

\subsection{Tuber and Fruit Virulence Assays}

The ability of strain EN21 to interfere with soft rot caused by D. solani IPO $2222^{\mathrm{T}}$, P. carotovorum subsp. carotovorum CECT $225^{\mathrm{T}}$ and Erwinia amylovora CECT $222^{\mathrm{T}}$ was assessed in potato and carrot slices and pear halves, respectively [24]. Briefly, potatoes (Solanum tuberosum), carrots (Daucus carota) and pears (Pyrus communis) were tap-washed and surface-sterilised by spraying with $1 \%(w / v)$ sodium hypochlorite solution, followed by $70 \%(v / v)$ ethanol and sterile distilled water. The potatoes and carrots were cut into slices $(0.5 \mathrm{~cm}$ in width), while the pears were cut down the middle under sterile conditions and arranged in petri dishes. The EN21-pathogen co-culture was prepared as described above- $5 \mu \mathrm{L}$ of the mixture were inoculated in the potato slices and pear halves with three equidistant incisions, while the carrot slices were inoculated with a single incision. Mono-cultures of each bacterium, as well as sterile distilled water, were similarly inoculated in potatoes, carrots and pears as controls. Nine replicates of each treatment were performed. After $24-48 \mathrm{~h}$ of incubation at $28{ }^{\circ} \mathrm{C}$, the maceration zones were visually detected and the extent of damage was calculated by image analysis using ImageJ software [47]. Co-culture plate counts were performed to verify the concentrations of the pathogen and strain EN21. 


\subsection{In Vivo Arabidopsis Plant Virulence Test}

The effect of AHL degradation by strain EN21 on P. syringae pv. tomato DC3000 virulence was tested in Arabidopsis plants using a technique described by Timmermann et al. [48] with slight modifications. Thus, Arabidopsis seeds were surface-sterilised and sown in 96-well plates with Murashige and Skoog medium [49] supplemented with $0.22 \mu \mathrm{m}$ filter sterilised sucrose to a final concentration of $7.3 \mathrm{mM}$. Plants were treated with sterile distilled water, the pathogen, strain EN21 and EN21-pathogen co-culture. Chlorophyll content was determined in fresh leaves by acetone extraction and absorbance reading [50-52]. Chlorophyll fluorescence images of Arabidopsis leaves were recorded under UV excitation (365 nm wavelenght) using a Leica DM5500 B fluorescence microscopy with LED illuminator system.

\subsection{In Vivo Tomato Plant Virulence Test}

The effect of AHL degradation by strain EN21 on P. syringae pv. tomato DC3000 virulence was tested in tomato plants using a technique described elsewhere [53]. Thus, tomato seeds were surface-sterilized and sown in pots as previously described in the plant growth promotion assay section. Plants were treated with sterile distilled water, the pathogen, strain EN21 and EN21-pathogen co-culture. Three pots containing 50 tomato seeds per pot were used for each treatment. For plants treated with strain EN21 and the co-culture, a $10 \mathrm{~mL}$ suspension of strain EN21 (109 CFU mL $\left.{ }^{-1}\right) \mathrm{was}^{9}$ inoculated weekly for 3 weeks to enable EN21 cells to interact and to establish plantlets, while the other two treatmentws were inoculated with $10 \mathrm{~mL}$ sterile distilled water. The pots were kept in an indoor greenhouse during a long-day photoperiod (16:8 h light:dark) at $25{ }^{\circ} \mathrm{C}$ for four weeks and watered with $50 \mathrm{~mL}$ sterile distilled water twice a week. After three weeks, the pots were exposed to $100 \%$ humidity for $16 \mathrm{~h}$ to induce stomatal opening and were then sprayed with a $5 \mathrm{~mL}$ P. syringae pv. tomato DC3000 suspension $\left(10^{9} \mathrm{CFU} \mathrm{mL} \mathrm{mL}^{-1}\right)$. Relative humidity was maintained at $100 \%$ for a further $24 \mathrm{~h}$ to facilitate pathogen infection. On day seven post-inoculation, affected and unaffected shoots were counted followed by plant harvesting. Shoots and roots were oven-dried to estimate dry weight. One hundred milligrams of fresh shoots were used to determine chlorophyll content as described above.

\subsection{Statistical Analysis}

Data normality was verified by the Shapiro-Wilk test and the data were statistically analysed with the aid of the ANOVA ( $p \leq 0.05)$ and Tukey tests using SPSS 24.0 software.

\section{Results}

\subsection{Characterization of Strain EN21}

Strain EN21 was isolated from the rhizosphere of Salicornia hispanica, which was taken from El Saladar del Margen (Cúllar, Granada, Spain) and was selected from a previous screening of 49 bacteria for their plant growth promotion properties. EN21 produced the enzymes ACC-deaminase, phosphatase and nitrogenase, hydrolysed cellulose and Tween 20, as well as siderophores and surfactants.

Complete 16S rRNA gene sequencing (1434 bp) confirmed that strain EN21 is a member of the bacterial genus Staphylococcus equorum, showing 99.86\% identity with strain S. equorum PA 231 ${ }^{\mathrm{T}}$ [54]. Its haloterant properties were attested by its growth in a wide range of salt concentrations $(0-25 \%(w / v)$ $\mathrm{NaCl})$ and, according to the Microtox test, does not show toxicity, with an $\mathrm{EC}_{50}$ of $125.7 \%$.

\subsection{Plant Growth Promotion Capacity of Strain EN21}

To evaluate its PGP activity, we performed a preliminary tomato seed bacterization experiment with S. equorum strain EN21. An increase in the shoot and root length of tomato seeds was observed in the inoculation with EN21 as compared to the non-inoculated control (Table 1 and Figure S1). Seed 
bacterization significantly increased both the germination rate and the vigour index by $15.7 \%$ and $24.4 \%$, respectively.

Table 1. Effects of S. equorum strain EN21 on tomato seed biopriming. Length values are expressed as the mean \pm SD. Increases in seedling length, germination rate and vigour index were calculated in relation to control seeds.

\begin{tabular}{ccc}
\hline & Control & Biopriming with EN21 \\
\hline Root length $(\mathrm{cm})$ & $2.7 \pm 1.0$ & $2.8 \pm 0.9$ \\
Root length increase $(\%)$ & - & 3.9 \\
Shoot length $(\mathrm{cm})$ & $2.3 \pm 0.7$ & $2.6 \pm 0.8$ \\
Shoot length increase $(\%)$ & - & 11.6 \\
Total length $(\mathrm{cm})$ & $5.0 \pm 1.6$ & $5.4 \pm 1.6$ \\
Total length increase $(\%)$ & - & 7.5 \\
Germination rate $(\%)$ & 77.8 & 90.0 \\
Germination rate increase $(\%)$ & - & 15.7 \\
Vigour index & 390.9 & 486.1 \\
Vigour index increase $(\%)$ & - & 24.4 \\
\hline
\end{tabular}

In vivo experiments were carried out to evaluate the PGP activity of strain EN21 in tomato plants. Plant inoculation with the strain tested in this study did not significantly affect growth promotion. However, combining seed bacterization with bacterial inoculation led to a significant improvement in plant growth (Table 2 and Figure S2). This improvement corresponded to longer plant shoots and higher levels of shoot and root dry weight as compared to the non-inoculated and non-bacterised controls (Table 2). We observed an increase of $110.5 \%$ in total plant dry weight, thus confirming that strain EN21 boosts plant growth. No statistical differences in root or total plant length in relation to the non-treated controls were observed.

Table 2. Effects of inoculation treatment and biopriming with strain EN21 on tomato plants. Length and dry weight values are expressed as the mean $\pm \mathrm{SD}$. * indicates statistically significant differences between treated plants and control $(p \leq 0.05)$.

\begin{tabular}{ccccc}
\hline & \multicolumn{2}{c}{ Inoculation Treatment } & \multicolumn{2}{c}{ Biopriming + Inoculation Treatment } \\
\cline { 2 - 5 } & Control & EN21 & Control & EN21 \\
\hline Root length $(\mathrm{cm})$ & $11.9 \pm 1.2$ & $11.8 \pm 1.4$ & $12.3 \pm 2.2$ & $12.1 \pm 1.7$ \\
Shoot length $(\mathrm{cm})$ & $18.2 \pm 2.8$ & $20.0 \pm 2.1$ & $19.3 \pm 1.6$ & $21.3 \pm 1.6^{*}$ \\
Total length $(\mathrm{cm})$ & $30.1 \pm 2.6$ & $31.8 \pm 1.7$ & $31.6 \pm 2.6$ & $33.4 \pm 2.7$ \\
Root dry weight $(\mathrm{g})$ & $0.028 \pm 0.013$ & $0.038 \pm 0.012$ & $0.017 \pm 0.004$ & $0.027 \pm 0.011^{*}$ \\
Shoot dry weight $(\mathrm{g})$ & $0.121 \pm 0.084$ & $0.173 \pm 0.051$ & $0.218 \pm 0.098$ & $0.466 \pm 0.071^{*}$ \\
Total dry weight $(\mathrm{g})$ & $0.149 \pm 0.090$ & $0.211 \pm 0.062$ & $0.234 \pm 0.101$ & $0.493 \pm 0.080^{*}$ \\
\hline
\end{tabular}

\subsection{QQ Activity of EN21 against Synthetic AHLs and Crude AHL Extracts From Pathogenic Bacteria}

We studied the capacity of EN21 to degrade a range of synthetic AHLs- $\mathrm{C}_{4}-\mathrm{HSL}, \mathrm{C}_{6}-\mathrm{HSL}$, 3-oxo- $\mathrm{C}_{6}$-HSL, $\mathrm{C}_{8}$-HSL, 3-oxo-C 8 -HSL, $\mathrm{C}_{10}$-HSL, 3-OH-C $10-\mathrm{HSL}, \mathrm{C}_{12}-\mathrm{HSL}, 3$-oxo- $\mathrm{C}_{12}-\mathrm{HSL}_{\text {and }} \mathrm{C}_{14}$-HSL. A well diffusion agar-plate assay with Agrobacterium tumefaciens NTL4 (pZLR4) biosensor strains was used to detect a wide range of AHLs, including Chromobacterium violaceum $\mathrm{CV} 026$ to detect $\mathrm{C}_{4}$-HSL and C. violaceum VIR07 to detect $\mathrm{C}_{10}-\mathrm{HSL}$ and 3-OH-C $10-\mathrm{HSL}$. S. equorum strain EN21 showed an intense QQ activity against the complete range of AHLs tested with no remaining AHLs detection except for $\mathrm{C}_{12}$-HSL in which degradation was not observed.

In addition, we evaluated the QQ activity of EN21 against crude AHL extracts from the following eight pathogenic strains-Agrobacterium fabrum C58 ATCC 33970 ${ }^{\mathrm{T}}$, Dickeya dianthicola DSM 18054 ${ }^{\mathrm{T}}$, D. solani IPO $2222^{\mathrm{T}}$, Erwinia amylovora CECT $222^{\mathrm{T}}$, Pectobacterium atrosepticum CECT $314^{\mathrm{T}}$, P. carotovorum subsp. carotovorum CECT $225^{\mathrm{T}}$, Pseudomonas syringae pv. syringae LMG $12472^{\mathrm{T}}$ and P. syringae pv. 
tomato DC3000. Our results indicate that EN21 is, to a greater or lesser extent, capable of degrading AHLs produced by all the pathogens tested except for D. dianthicola which AHLs were not affected by EN21 strain. A strong AHLs degradation was achieved for A. fabrum, D. solani, P. s. pv. syringe and P. s. pv. tomato, while partial degradation was reached for E. amylovora, P. atrosepticum and P. carotovorum subsp. carotovorum. Figure 1 shows the significant degradation of certain AHLs caused by EN21.

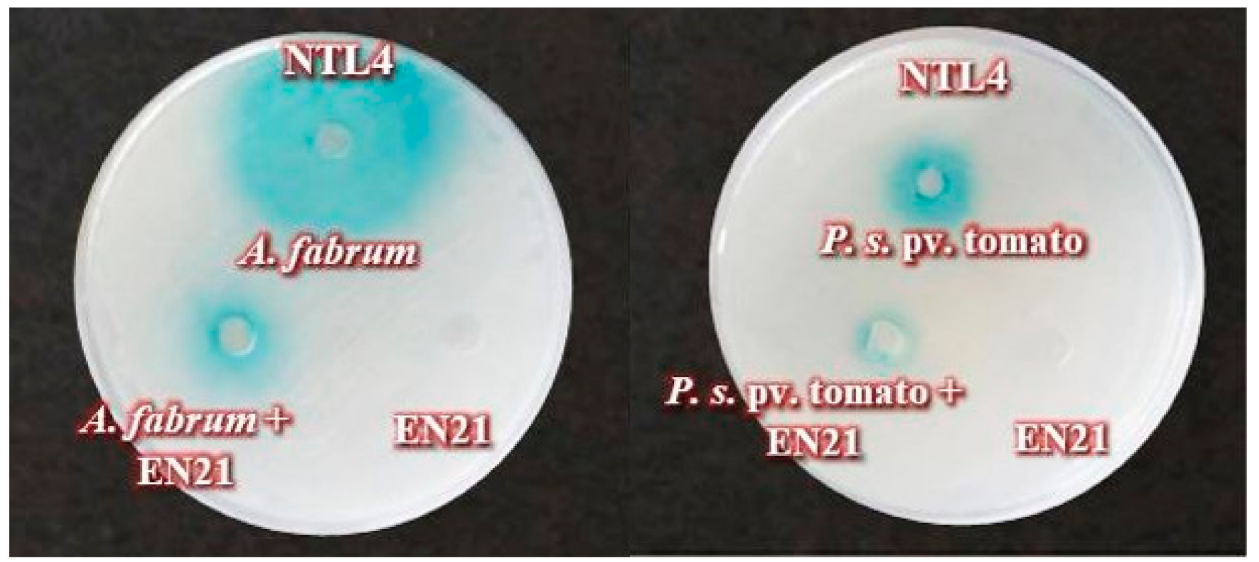

Figure 1. Quorum quenching (QQ) activity of strain EN21 against crude N-acyl homoserine lactone (AHL) extracts from A. fabrum and P. syringae. pv. tomato.

\subsection{Attenuation of Phytopathogenic Virulence Factors in Co-Cultures with EN21}

EN21-phytopathogen co-cultures were used to analyse the repercussion of AHLs degradation on phytopathogens virulence attenuation. Using antagonist experiments, we first confirmed that EN21 did not interfere with growth in any of the eight plant pathogens tested. Each pathogen was grown in a co-culture with EN21 (ratio 1:100). After $24 \mathrm{~h}$ of incubation, the remaining AHLs were detected using the biosensor A. tumefaciens NTL4 (pLZR4). All AHLs produced by each pathogen, except for $D$. dianthicola, were partially degraded, which is in line with our previous findings. The same co-cultures were used to analyse the effect of AHL degradation on QS-regulated cellular functions. In the co-cultures with EN21, we observed a reduction in enzymatic activities such as caseinase, DNase and lecithinase in D. solani IPO $2222^{\mathrm{T}}$, as well as amylase in P. syringae pv. syringae $\mathrm{LMG} 1247^{\mathrm{T}}$ and P. syringae pv. tomato DC3000 (Table S1).

\subsection{EN21 Enhances Disease Resistance to Phytopathogens in Tubers and Fruits}

We carried out experiments on potatoes, carrots and pears which demonstrated the effectiveness of QS interruption by EN21 against D. solani IPO $2222^{\mathrm{T}}$, P. carotovorum subsp. carotovorum CECT $225^{\mathrm{T}}$ and Erwinia amylovora CECT $222^{\mathrm{T}}$, respectively. Bacterial mono-cultures and EN21-pathogen co-cultures were prepared under the conditions described above. Potato tubers infected with the D. solani IPO $2222^{\mathrm{T}}$ mono-culture produced large maceration zones (25\%), while a reduction in soft rot symptoms (5\% maceration) was observed in the pathogen-EN21 co-culture (Figure S3A and Figure 2). When inoculated with the EN21-P. carotovorum subsp. carotovorum CECT $225^{\mathrm{T}}$ co-culture, the carrot slices showed less maceration (Figure S3B and Figure 2). QS interruption by EN21 was highly effective in pears, with almost a $90 \%$ reduction in maceration caused by E. amylovora CECT $222^{\mathrm{T}}$-induced fire blight in the EN21-pathogen co-culture (Figure S3C and Figure 2). The concentrations of strain EN21 and each pathogen, measured by plate counting, were found to be similar throughout the experiment. Thus, strain EN21 proved to be capable of biologically controlling different host and phytopathogen types. 
Control

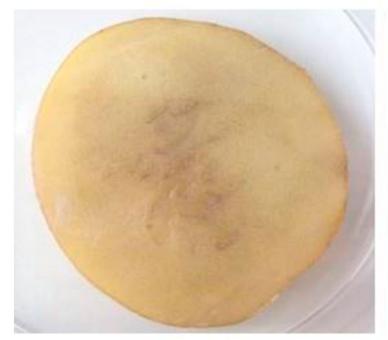

Control

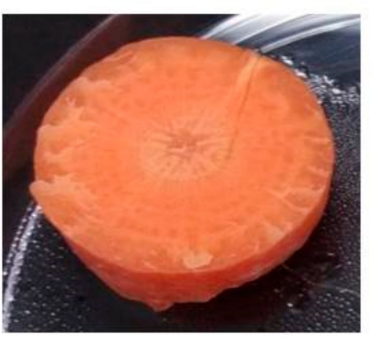

Control

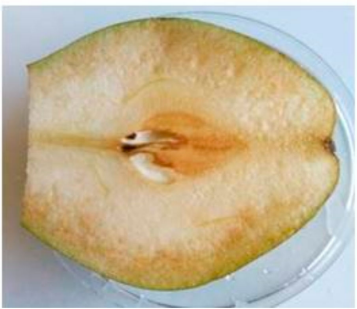

EN21

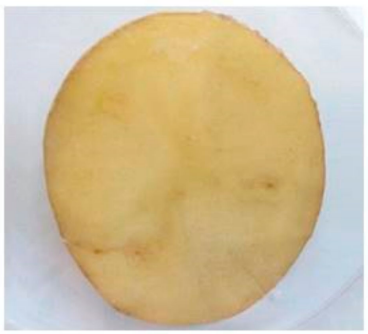

EN21

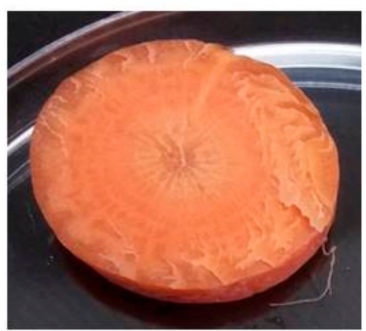

EN21

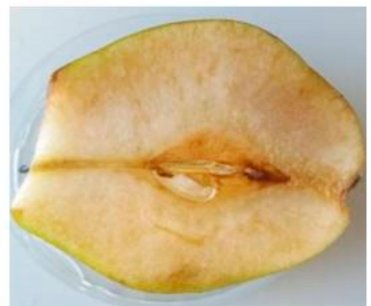

D. solani

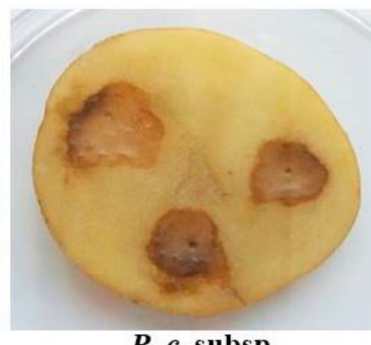

P. c. subsp. carotovorum

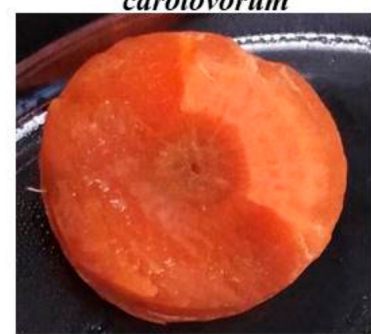

E. amylovora

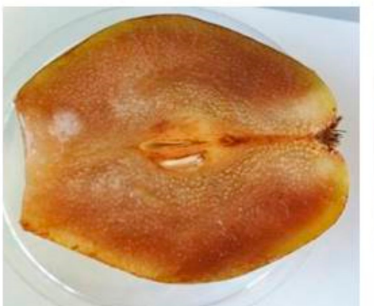

D. solani + EN21

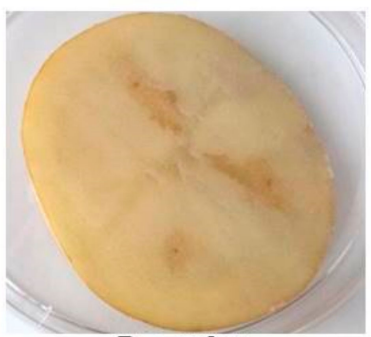

P. c. subsp.

carotovorum + EN21

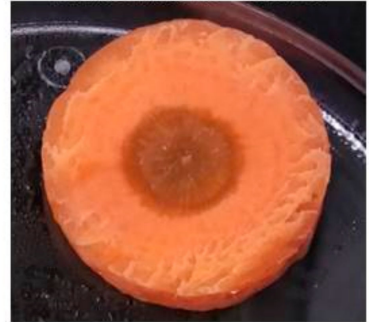

E. amylovora + EN21

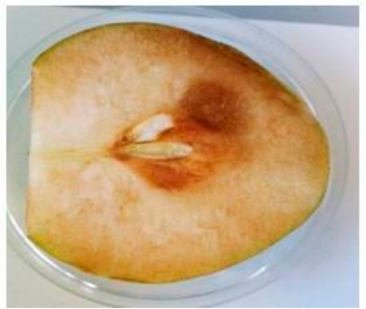

Figure 2. Effect of EN21 AHL-degrading activity against bacterial plant pathogens in potato tuber, carrot and pear assays. Tissues were inoculated with sterile water (control), EN21 and phytopathogen mono-cultures and phytopathogen-EN21 co-cultures (from left to right in panel).

\subsection{EN21 Reduces P. syringae pv. Tomato DC3000 Virulence in Model Plant Arabidopsis}

Disease spread caused by P. syringae pv. tomato DC3000 in Arabidopsis plants was monitored by visually inspecting leaf tissue chlorosis at $3 \mathrm{dpi}$. We used microscopic monitoring to assess Arabidopsis plant responses to this phytopathogen in the presence and absence of strain EN21. The pathogen was inoculated and disease symptoms on the leaf were examined under differential interference contrast (DIC) and epifluorescence (UV excitation filter) microscopes. Bacterial cell numbers, inspected over time, remained stable throughout the monitoring period $\left(10^{8} \mathrm{CFU} \mathrm{mL}{ }^{-1}\right)$. Chlorophyll fluorescence imaging showed that $P$. syringae pv. tomato DC3000 caused visible disease symptoms on plants, with a sharp decrease observed in chlorophyll content (Figure 3). However, we found that EN21 had a protective effect on pathogen-infected plants. The EN21-treated plants appeared to be very similar to the non-infected control plants; with the aid of DIC and epifluorescence microscopy, non-infected and EN21-treated Arabidopsis plants, as well as those treated with the pathogen-EN21 co-culture, were observed to have more intact inner tissue and larger numbers of chloroplasts per cell than pathogen-infected plants (Figure 3). 
Control
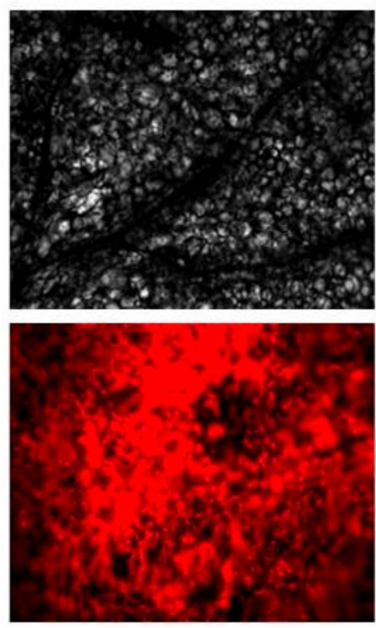

EN21
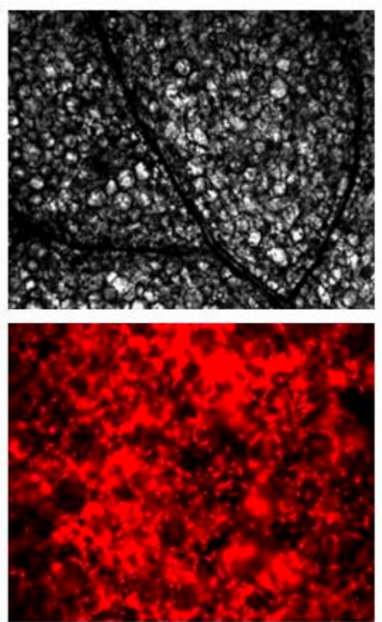

P. s. pv. tomato
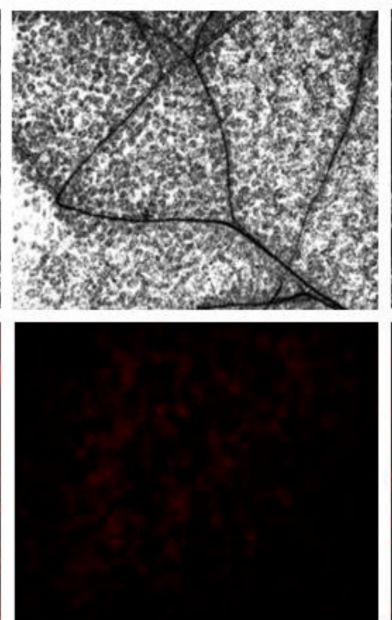

P. s. pv. tomato + EN21
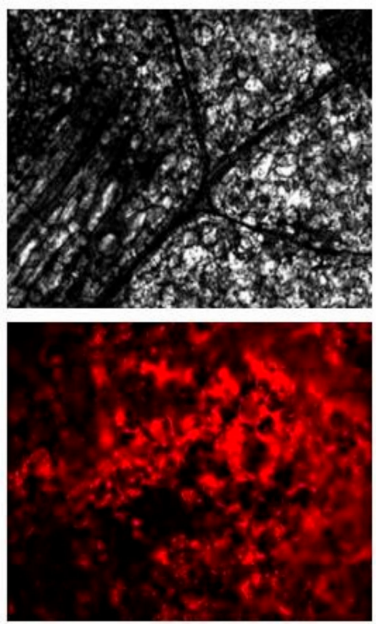

Figure 3. Visualization of tissue structure and chlorophyll content in Arabidopsis leaves by differential interference contrast (DIC) and epifluorescence microscopy 100× (first and second row, respectively). Leaves were inoculated with sterile water (control), EN21 and phytopathogen mono-cultures and phytopathogen-EN21 co-culture (from left to right in panel). Micrographs from each row were taken under the same exposure time, gamma and gain values for comparative analysis. Epifluorescence images were digitally coloured.

The chlorophyll content of Arabidopsis leaves is an indirect indicator of the plant's health status, with the data presented in Table 3 demonstrating a sharp reduction in both types a and b of chlorophyll in P. syringae pv. tomato DC3000-infected Arabidopsis leaves and a partial recovery in total chlorophyll with the pathogen-EN21 co-culture. Chlorophyll levels in EN21-treated leaves were similar to those detected in control leaves.

Table 3. Chlorophyll quantification in the virulence loss test of $P$. syringae pv. tomato in $A$. thaliana.

\begin{tabular}{|c|c|c|c|c|c|c|}
\hline & \multicolumn{2}{|c|}{ Chlorophyll a ( $\mu \mathrm{g} \mathrm{mL}^{-1)}$} & \multicolumn{2}{|c|}{ Chlorophyll b ( $\left.\mu \mathrm{g} \mathrm{mL}^{-1}\right)$} & \multicolumn{2}{|c|}{ Total Chlorophyll $\left(\mu \mathrm{g} \mathrm{mL}^{-1}\right)$} \\
\hline & Arnon & Lichtenthaler & Arnon & Lichtenthaler & Arnon & Lichtenthaler \\
\hline Control & 1.39 & 1.33 & 0.55 & 0.38 & 1.95 & 1.72 \\
\hline EN21 & 1.24 & 1.18 & 0.53 & 0.39 & 1.77 & 1.57 \\
\hline P.s. pv. tomato & 0.14 & 0.13 & 0.08 & 0.06 & 0.22 & 0.19 \\
\hline P. s. pv. tomato + EN21 & 0.34 & 0.32 & 0.23 & 0.18 & 0.57 & 0.51 \\
\hline
\end{tabular}

\subsection{EN21 Reduces P. syringae pv. Tomato Virulence in Tomato Plants}

Disease spread caused by P. syringae pv. tomato DC3000 was monitored in previously bacterised tomato plants by visually inspecting leaf tissue chlorosis at 3 dpi (Figure 4 ) and by measuring total plant dry weight and chlorophyll levels post treatment. The application of EN21-P. syringae pv. tomato DC3000 co-cultures to tomato plants revealed that strain EN21 is a promising biocontrol agent. 


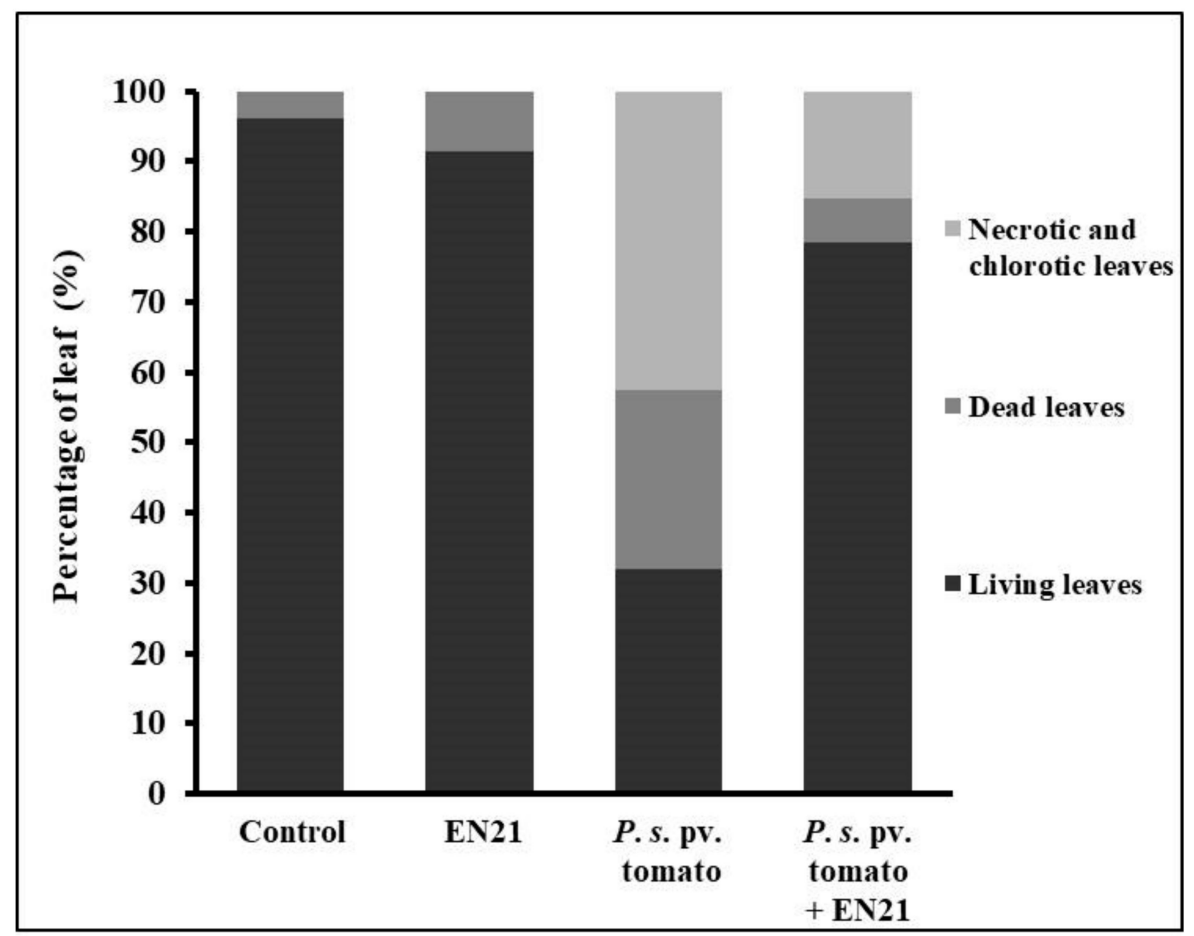

Figure 4. Percentage of living, dead, necrotic and chlorotic tomato leaves. Leaves were inoculated with sterile water (control), EN21 and phytopathogen mono-cultures and phytopathogen-EN21 co-culture.

The shoot, root and total dry weight of the plants is given in Table 4. Although the results indicate that the total dry weight of pathogen-infected tomato plants decreased, tomato plants treated with EN21 and the EN21-phytopathogen co-culture remained unchanged with respect to this parameter as compared to the non-infected plants. We were unable to evaluate the PGP activity of EN21 in this experiment due to the short time period (5-7 days) involved.

Table 4. Effects of inoculation with strain EN21, P. syringae pv. tomato and EN21+ P. syringae pv. tomato co-culture on tomato plants. Dry weight values are expressed as the mean \pm SD. ${ }^{*}$ indicates statistically significant differences between treated plants and control $(p<0.05)$.

\begin{tabular}{ccccc}
\hline & Control & EN21 & P. s. pv. Tomato & P. s. pv. Tomato + EN21 \\
\hline Root dry weight (g) & $0.015 \pm 0.005$ & $0.022 \pm 0.006$ & $0.009 \pm 0.003$ & $0.016 \pm 0.003$ \\
Shoot dry weight (g) & $0.032 \pm 0.007$ & $0.041 \pm 0.010$ & $0.016 \pm 0.005^{*}$ & $0.032 \pm 0.006$ \\
Total dry weight (g) & $0.048 \pm 0.010$ & $0.063 \pm 0.015$ & $0.024 \pm 0.008^{*}$ & $0.048 \pm 0.008$ \\
\hline
\end{tabular}

Using visual monitoring, we detected symptoms of infection in leaves treated with the pathogen alone and the EN21-pathogen co-culture (Figure 5). However, severe symptoms, with large numbers of chlorotic leaves and necrotic lesions, were observed in P. syringae pv. tomato-infected plants. We observed a sharp reduction in dead, necrotic and chlorotic leaves treated with the EN21-pathogen co-culture, which was similar to the pattern found in EN21-treated control plants. The photographs of plants in Figure 5 show the reduction caused by EN21 in disease symptoms, which is in line with the effects previously observed in the model plant Arabidopsis. It also demonstrates the potential of S. equorum strain EN21 to be used as an effective phytopathogen biocontrol agent. 


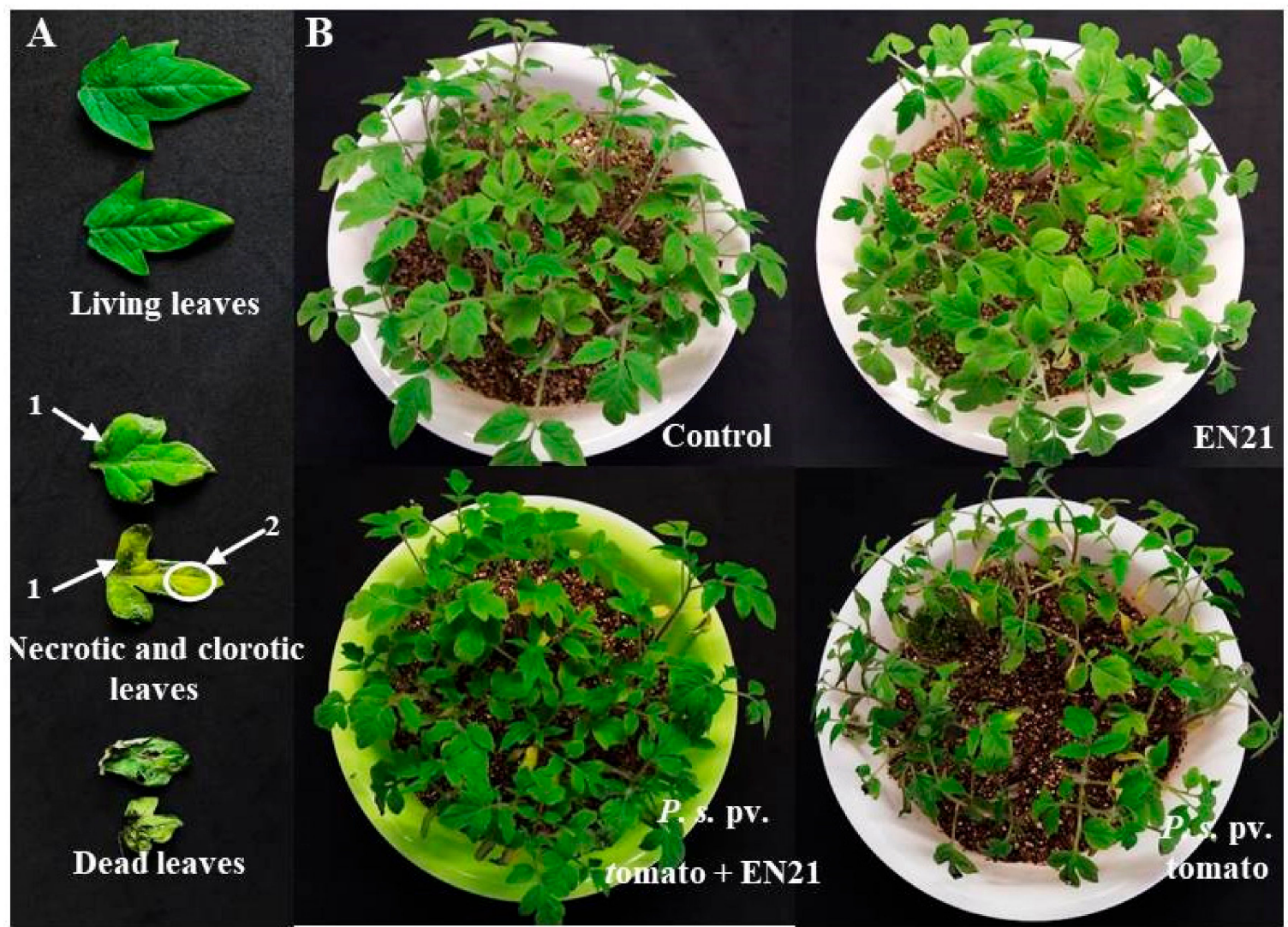

Figure 5. Tomato plants sprayed with sterile water (control), EN21, P. syringae pv. tomato and $P$. syringae pv. tomato + EN21 (B). Disease symptoms were inspected and photographed three days after infection (A). Necrotic (1A) and clorotic (2A) symptoms were observed.

As with Arabidopsis plants, we observed a sharp reduction in types a and b of chlorophyll in P. syringae pv. tomato DC3000-infected tomato leaves, while the pathogen-EN21co-culture caused a partial recovery in total chlorophyll (Table 5). Chlorophyll levels in EN21-treated leaves were similar those observed in the controls.

Table 5. Chlorophyll quantification in tomato plants.

\begin{tabular}{ccccccc}
\hline & \multicolumn{2}{c}{ Chlorophyll a $\left(\mathbf{m g ~ g}^{-1}\right)$} & \multicolumn{2}{c}{ Chlorophyll b $\left(\mathbf{m g ~ g}^{-\mathbf{1}}\right)$} & \multicolumn{2}{c}{ Total Chlorophyll $\left(\mathbf{m g ~ g ~}^{-\mathbf{1}}\right)$} \\
\cline { 2 - 7 } & Arnon & Lichtenthaler & Arnon & Lichtenthaler & Arnon & Lichtenthaler \\
\hline Control & 0.62 & 0.29 & 0.26 & 0.09 & 0.87 & 0.37 \\
EN21 & 0.51 & 0.24 & 0.21 & 0.08 & 0.72 & 0.32 \\
P. s. pv. tomato & 0.57 & 0.27 & 0.24 & 0.09 & 0.81 & 0.36 \\
P.s. pv. tomato + EN21 & 0.76 & 0.37 & 0.33 & 0.12 & 1.10 & 0.48 \\
\hline
\end{tabular}

\section{Discussion}

Global climate change currently affects crop growth, quality and yields which could be significantly improved by a sustainable and efficient strategy involving plant growth-promoting rhizobacteria (PGPR).

In a previous screening of 49 soil bacteria, strain EN21, which was isolated from the halophytic plant Salicornia hispanica, was found to contain the most effective PGP activity. With the aid of 16S rRNA gene sequencing, EN21 was identified as belonging to the bacterial species Staphylococcus equorum. Although the PGP activity and biocontrol potential of bacteria such as Pseudomonas sp. isolated from halophytes have been extensively studied [55], very little is known about the bacterium S. equorum. Also, while PGP activity in the bacteria S. cohnii, S. capitis and S. warneri of the genus Staphylococcus has 
previously been described [56], to our knowledge, only two studies have characterized this activity in S. equorum strains Se1 and Se2 isolated from halophytes in Arabidopsis thaliana, which showed an increase in weight and root length $[57,58]$.

Jeong et al. [59] have highlighted the halotolerance of $S$. equorum, which can withstand salt concentrations of 0 to $25 \%(w / v) \mathrm{NaCl}$, while other studies have described the safety and technological characteristics of this bacterium, which was isolated from various fermented foods. While Jeong et al. [59] found that S. equorum lacks functional virulence factors, our Microtox test also confirmed the non-toxic nature of strain EN21, with an $\mathrm{EC}_{50}$ of $125.7 \%$.

Using biopriming studies and in vivo experiments, we evaluated the PGP activity of S. equorum strain EN21 in tomato plants under sterile conditions. However, plant inoculation treatment, which was insufficient on its own, needed to be combined with biopriming for the bacterium to generate significant plant growth. An increase in shoot and root dry weight and shoot length was observed in EN21-treated tomato plants as compared to controls plants. Seed biopriming with living bacterial inocula has been reported to improve harvest quality and yields [60]. Earlier studies have also shown the benefits of combining biopriming and inoculation with commercial biofertilizers containing bacterial species, such as Pseudomonas sp. and Bacillus subtilis, in plant growth promotion [61,62].

We investigated the strategy of combining plant growth promotion rhizobacteria with pathogen communication silencing to control bacterial plant infections, with the virulence factors of many bacterial phytopathogens having been found to be regulated by QS systems [22,23]. One promising strategy to combat infection is based on QQ signal inactivation by AHL signalling molecule degradation. We evaluated the efficiency of QS by S. equorum strain EN21 with respect to a wide range of synthetic AHLs and crude AHL extracts from pathogenic bacteria such as Agrobacterium fabrum C58 ATCC $33970^{\mathrm{T}}$, Dickeya dianthicola DSM $18054^{\mathrm{T}}$, D. solani IPO $2222^{\mathrm{T}}$, Erwinia amylovora CECT $222^{\mathrm{T}}$, Pectobacterium atrosepticum CECT $314^{\mathrm{T}}$, P. carotovorum subsp. carotovorum CECT $225^{\mathrm{T}}$, Pseudomonas syringae pv. syringae LMG $1247^{\mathrm{T}}$ and P. syringae pv. tomato DC3000. AHL degradation was effective in all cases except for D. dianthicola. In the EN21-phytopathogen co-culture experiments, we observed an attenuation of some virulence factors. AHL interference activity has also been shown to inhibit the virulence factors of QS-regulated excreted QQ yayurea compounds A and B [15].

To our knowledge, the QQ activity of Staphylococcus sp. against phytopathogens has not been studied. Newman et al. [63] have reported that pathogenic bacterial virulence in plants is attenuated by this genus but by the degradation of fatty acid cell-to-cell signalling factors and diffusible signal factors (DSFs). Another study found that staphylococcal species, such as S. delphini, S. intermedius and S. lutrae, that excrete quorum quenching compounds called yayurea (A and B) suppress QS signalling and inhibit the growth of P. aeruginosa [64]. However, it found no QQ activity against $P$. aeruginosa by S. equorum subsp. equorum DSMZ 20674 .

The highly effective quorum quenching of EN21 correlates with its capacity to degrade AHLs, as demonstrated by in vitro experiments on potatoes, carrots and pears to evaluate the QQ activity of EN21 in tubers and fruits. These experiments showed the effective interruption of QS by EN21 in Dickeya solani, Pectobacterium carotovorum subsp. carotovorum and Erwinia amylovora. Bacterial cell numbers were inspected over time and remained stable throughout the monitoring period, indicating that the reduction in phytopathogenic virulence by EN21 was due to effective QS interruption and not pathogen growth inhibition. Although similar results have been described with respect to other bacteria such as Bacillus spp., antibiotic activity can interfere with bacterial growth $[65,66]$.

In vivo experiments with model plant Arabidopsis thaliana also detected EN21 quorum quenching activity against $P$. syringae pv. tomato DC3000, with chlorophyll fluorescence images of leaves showing how pathogen-infected plants are protected by EN21. DIC microscopy revealed intact inner tissue and a larger number of chloroplasts per cell in leaves treated with the pathogen-EN21 co-culture. Two studies have reported the effectiveness of measuring chlorophyll fluorescence to rapidly screen photosynthetic processes involved in the health status of plants $[67,68]$. Our study shows a sharp 
reduction in chlorophyll in P. syringae pv. tomato-infected Arabidopsis leaves and a partial recovery in total chlorophyll levels after treatment with the pathogen-EN21co-culture.

Our in vivo experiments with P. syringae pv. tomato-inoculated tomato plants revealed that treatment with strain EN21 could be an ideal phytopathogen biocontrol agent. In these experiments, P. syringae pv. tomato-infected plants underwent an excellent recovery, as indicated by dry weight, chlorophyll levels and disease symptoms in the biocontrol assays. A sharp reduction in dead, necrotic and chlorotic leaves was observed following EN21 treatment of pathogen-infected plants. All these findings with respect to tomato plants are in line with those for the model plant Arabidopsis thaliana.

Previous studies showed the reduction of soft rot symptoms produced by Pectobacterium carotovorum by transformed strains with an AHL-degrading gene, such as Lysobacter enzymogenes or Pseudomonas putida [69,70]. The reduction in phytopathogen virulence by QQ activity has also been studied in other bacteria such as Pseudomonas fluorescens [66], some of whose antibiotic production can inhibit tomato plant root development [71] and trigger antibiotic resistance in many bacterial phytopathogens.

Little is known about the biological control potential of halotolerant bacteria based on AHL degradation. Nevertheless, the inoculation of crops with natural halotolerant PGPR strains such as S. equorum strain EN21, with its high quorum quenching capacity, could be an important biocontrol strategy for both saline and non-saline soils, whose principal advantages are the prevention of antibiotic resistance and use of genetically engineered bacteria.

Supplementary Materials: Supplementary materials can be found at http://www.mdpi.com/2076-2607/8/1/42/s1.

Author Contributions: C.V., M.R., I.S. and I.L. conceived and supervised the study; I.S. and I.L. designed the experiments; C.V. and M.R. performed the experiments; C.V., M.R. and I.S. analysed the data; C.V. and I.S. prepared the figures and wrote the manuscript; C.V., M.R., V.B., I.S. and I.L. edited the manuscript and reviewed the literature. All authors have read and agreed to the published version of the manuscript.

Funding: The study was funded by the Ramón y Cajal MINECO program (RYC-2014-15532) in Spain.

Acknowledgments: I.S. wishes to thank MINECO for her Ramón and Cajal contract, M.R. wishes to thank MITRAMISS for his "Joven Investigador" contract, Michael O'Shea corrected the English version of the manuscript and Clementina Pozo bioassayed the toxicity of EN21. The authors thank Juan Sanjuan Pinilla research group (EEZ, CSIC) for kindly supply Pseudomonas syringae pv. tomato DC3000 strain.

Conflicts of Interest: The authors declare no conflict of interest. The funders had no role in the design of the study; in the collection, analyses, or interpretation of data; in the writing of the manuscript, or in the decision to publish the results.

\section{References}

1. Ashraf, M.Y.; Awan, A.R.; Mahmood, K. Rehabilitation of saline ecosystems through cultivation of salt tolerant plants. Pak. J. Bot. 2012, 44, 69-75.

2. Almasri, M.N.; Kaluarachchi, J.J. Implications of on-ground nitrogen loading and soil transformations on ground water quality management. J. Am. Water Resour. Assoc. 2004, 40, 165-186. [CrossRef]

3. Reddy, P.P. Plant Growth Promoting Rhizobacteria for Horticultural Crop Protection, 1st ed.; Springer: New Delhi, India, 2014; pp. 4-15.

4. Sharma, A.; Vaishnav, A.; Jamali, H.; Srivastava, A.K.; Saxena, A.K.; Srivastava, A.K. Halophilic bacteria: Potential bioinoculants for sustainable agriculture and environment management under salt stress. In Plant-Microbe Interaction: An Approach to Sustainable Agriculture, 1st ed.; Devendra, K.C., Ajit, V., Narenda, T., Eds.; Springer: Singapore, 2016; pp. 297-325.

5. Gajdács, M.; Spengler, G. The role of drug repurposing in the development of novel antimicrobial drugs: Non-antibiotic pharmacological agents as quorum sensing-inhibitors. Antibiotics 2019, 8, 270. [CrossRef] [PubMed]

6. Li, Z.; Nair, S.K. Quorum sensing: How bacteria can coordinate activity and synchronize their response to external signals? Protein Sci. 2012, 21, 1403-1417. [CrossRef]

7. Papenfort, K.; Bassler, B.L. Quorum sensing signal-response systems in Gram-negative bacteria. Nat. Rev. Microbiol. 2016, 14, 576-588. [CrossRef] 
8. Whiteley, M.; Diggle, S.P.; Greenberg, E.P. Progress in and promise of bacterial quorum sensing research. Nature 2017, 551, 313-320. [CrossRef]

9. Fuqua, W.C.; Winans, S.C.; Greenberg, E.P. Quorum sensing in bacteria: The LuxR-LuxI family of cell density-responsive transcriptional regulators. J. Bacteriol. 1994, 176, 269-275. [CrossRef]

10. Deziel, E.; Lepine, F.; Milot, S.; He, J.; Mindrinos, M.N.; Tompkins, R.G.; Rahme, L.G. Analysis of Pseudomonas aeruginosa 4-hydroxy-2-alkylquinolines (HAQs) reveals a role for 4-hydroxy-2-heptylquinoline in cell-to-cell communication. Proc. Natl. Acad. Sci. USA 2004, 101, 1339-1344. [CrossRef]

11. Barber, C.E.; Tang, J.L.; Feng, J.X.; Pan, M.Q.; Wilson, T.J.; Slater, H.; Dow, J.M.; Williams, P.; Daniels, M.J. A novel regulatory system required for pathogenicity of Xanthomonas campestris is mediated by a small diffusible signal molecule. Mol. Microbiol. 1997, 24, 555-566. [CrossRef] [PubMed]

12. Quinones, B.; Dulla, G.; Lindow, S.E. Quorum sensing regulates exopolysaccharide production, motility, and virulence in Pseudomonas syringae. Mol. Plant Microbe Interact. 2005, 18, 682-693. [CrossRef] [PubMed]

13. Venturi, V.; Venuti, C.; Devescovi, G.; Lucchese, C.; Friscina, A.; Degrassi, G.; Aguilar, C.; Mazzucchi, U. The plant pathogen Erwinia amylovora produces acyl-homoserine lactone signal molecules in vitro and in planta. FEMS Microbiol. Lett. 2004, 241, 179-183. [CrossRef] [PubMed]

14. Von Bodman, S.B.; Bauer, W.D.; Coplin, D.L. Quorum sensing in plant-pathogenic bacteria. Annu. Rev. Phytopathol. 2003, 41, 455-482. [CrossRef] [PubMed]

15. Torres, M.; Dessaux, Y.; Llamas, I. Saline environments as a source of potential quorum sensing disruptors to control bacterial infections: A review. Mar. Drugs 2019, 17, 191. [CrossRef] [PubMed]

16. Crépin, A.; Beury-Cirou, A.; Barbey, C.; Farmer, C.; Hélias, V.; Burini, J.-F.; Faure, D.; Latour, X. N-acyl homoserine lactones in diverse Pectobacterium and Dickeya plant pathogens: Diversity, abundance, and involvement in virulence. Sensors 2012, 12, 3484-3497. [CrossRef] [PubMed]

17. Dessaux, Y.; Faure, D. Quorum sensing and quorum quenching in Agrobacterium: A “Go/No Go System”? Genes 2018, 9, 210. [CrossRef]

18. Fetzner, S. Quorum quenching enzymes. J. Biotechnol. 2015, 201, 2-14. [CrossRef]

19. Han, Y.; Chen, F.; Li, N.; Zhu, B.; Li, X. Bacillus marcorestinctum sp. nov., a novel soil acylhomoserine lactone quorum-sensing signal quenching bacterium. Int. J. Mol. Sci. 2010, 11, 507-520. [CrossRef]

20. Uroz, S.; D'Angelo-Picard, C.; Carlier, A.; Elasri, M.; Sicot, C.; Petit, A.; Oger, P.; Faure, D.; Dessaux, Y. Novel bacteria degrading $\mathrm{N}$-acylhomoserine lactones and their use as quenchers of quorum-sensing-regulated functions of plant-pathogenic bacteria. Microbiology 2003, 149, 1981-1989. [CrossRef]

21. Uroz, S.; Chhabra, S.R.; Cámara, M.; Williams, P.; Oger, P.; Dessaux, Y. N-Acylhomoserine lactone quorum-sensing molecules are modified and degraded by Rhodococcus erythropolis W2 by both amidolytic and novel oxidoreductase activities. Microbiology 2005, 151, 3313-3322. [CrossRef]

22. Faure, D.; Dessaux, Y. Quorum sensing as a target for developing control strategies for the plant pathogen Pectobacterium. Eur. J. Plant Pathol. 2007, 119, 353-365. [CrossRef]

23. Helman, Y.; Chernin, L. Silencing the mob: Disrupting quorum sensing as a means to fight plant disease. Mol. Plant Pathol. 2015, 16, 316-329. [CrossRef] [PubMed]

24. Torres, M.; Uroz, S.; Salto, R.; Fauchery, L.; Quesada, E.; Llamas, I. HqiA, a novel quorum-quenching enzyme which expands the AHL lactonase family. Sci. Rep. 2017, 7, 943. [CrossRef] [PubMed]

25. Reina, J.C.; Torres, M.; Llamas, I. Stenotrophomonas maltophilia AHL-degrading strains isolated from marine invertebrate microbiota attenuate the virulence of Pectobacterium carotovorum and Vibrio coralliilyticus. Mar. Biotechnol. 2019, 21, 276-290. [CrossRef] [PubMed]

26. McClean, K.H.; Winson, M.K.; Fish, L.; Taylor, A.; Chhabra, S.R.; Cámara, M.; Daykin, M.; Lamb, J.H.; Swift, S.; Bycroft, B.W.; et al. Quorum sensing and Chromobacterium violaceum: Exploitation of violacein production and inhibition for the detection of N-acylhomoserine lactones. Microbiology 1997, 143, 3703-3711. [CrossRef] [PubMed]

27. Morohoshi, T.; Kato, M.; Fukamachi, K.; Kato, N.; Ikeda, T. N-acylhomoserine lactone regulates violacein production in Chromobacterium violaceum type strain ATCC 12472. FEMS Microbiol. Lett. 2008, 279, 124-130. [CrossRef]

28. Chilton, M.D.; Currier, T.C.; Farrand, S.K.; Bendich, A.J.; Gordon, M.P.; Nester, E.W. Agrobacterium tumefaciens DNA and PS8 bacteriophage DNA not detected in crown gall tumors. Proc. Natl. Acad. Sci. USA 1974, 71, 3672-3676. [CrossRef] 
29. Moraine, R.A.; Rogovin, P. Kinetics of polysaccharide B-1459 fermentation. Biotechnol. Bioeng. 1966, 8, 511-524. [CrossRef]

30. Rodríguez-Valera, F.; Ruíz-Berraquero, F.; Ramos-Cormenzana, A. Characteristics of the heterotrophic bacterial populations in hypersaline environments of different salt concentrations. Microb. Ecol. 1981, 7, 235-243. [CrossRef]

31. Pikovskaya, R.I. Mobilization of phosphorus in soil connection with the vital activity of some microbial species. Microbiology 1984, 17, 362-370.

32. Baird-Parker, A.C. A classification of micrococci and staphylococci based on physiological and biochemical tests. J. Gen. Microbiol. 1963, 30, 409-427. [CrossRef]

33. Uttley, A.; Collins, C. Theory and practice of bacterial identification. In Cowan and Steel's Manual for the Identification of Medical Bacteria, 3rd ed.; Barrow, G.I., Feltham, R.K.A., Eds.; Cambridge University Press: Cambridge, UK, 1993; pp. 46-49.

34. Villalba, L.S.; Mikan, J.; Sánchez, J. Actividades hidrolíticas y caracterización isoenzimática de poblaciones microbianas aisladas del patrimonio documental del Archivo General de Colombia. Nova 2004, 2, 50-58. [CrossRef]

35. Castro, R.; Álvarez, A.; Machado, E.; Mendoza, M.; Gómez, R.; García, P. Characterization of a extracellular chitinase produced by Serratia sp. BIOMI-363706 using colloidal chitin as substrate. Rev. Soc. Quím. Perú 2011, 77, 101-108.

36. Jeffries, C.D.; Holtman, D.F.; Guse, D.G. Rapid method for determining the activity of microorganisms on nucleic acids. J. Bacteriol. 1957, 73, 590-591. [PubMed]

37. Schwyn, B.; Neilands, J. Universal chemical assay for the detection and determination of siderophores. Anal. Biochem. 1987, 160, 47-56. [CrossRef]

38. Ajuzieogu, C.; Odokuma, L. Toxicity assessment of produced water using Microtox Rapid Bioassay. South Asian J. Res. Microbiol. 2018, 1, 1-9. [CrossRef]

39. Altschul, S.F.; Gish, W.; Miller, W.; Myers, E.W.; Lipman, D.J. Basic local alignment search tool. J. Mol. Biol. 1990, 215, 403-410. [CrossRef]

40. Yoon, S.H.; Ha, S.M.; Kwon, S.; Lim, J.; Kim, Y.; Seo, H.; Chun, J. Introducing EzBioCloud: A taxonomically united database of $16 \mathrm{~S}$ rRNA gene sequences and whole-genome assemblies. Int. J. Syst. Evolut. Microbiol. 2017, 67, 1613-1617. [CrossRef]

41. Abdul-Baki, A.A.; Anderson, J.D. Vigor determination in soybean seed by multiple criteria. Crop Sci. 1973, 13, 630-633. [CrossRef]

42. Romero, M.; Martín-Cuadrado, A.-B.; Roca-Rivada, A.; Cabello, A.M.; Otero, A. Quorum quenching in cultivable bacteria from dense marine coastal microbial communities. FEMS Microbiol. Ecol. 2011, 75, $205-217$. [CrossRef]

43. Torres, M.; Rubio-Portillo, E.; Antón, J.; Ramos-Espla, A.A.; Quesada, E.; Llamas, I. Selection of the $\mathrm{N}$-Acylhomoserine lactone-degrading bacterium Alteromonas stellipolaris PQQ-42 and of its potential for biocontrol in aquaculture. Front. Microbiol. 2016, 7, 646. [CrossRef]

44. Marketon, M.M.; Gonzalez, J.E. Identification of two quorum-sensing systems in Sinorhizobium meliloti. J. Bacteriol. 2002, 184, 3466-3475. [CrossRef] [PubMed]

45. Llamas, I.; Quesada, E.; Martínez-Canovas, M.J.; Gronquist, M.; Eberhard, A.; Gonzalez, J.E. Quorum sensing in halophilic bacteria: Detection of N-acyl-homoserine lactones in the exopolysaccharide-producing species of Halomonas. Extremophiles 2005, 9, 333-341. [CrossRef] [PubMed]

46. Frikha-Gargouri, O.; Ben Abdallah, D.; Bhar, I.; Tounsi, S. Antibiosis and bmyB gene presence as prevalent traits for the selection of efficient Bacillus biocontrol agents against crown gall disease. Front. Plant Sci. 2017, 8, 1363. [CrossRef] [PubMed]

47. Schneider, C.A.; Rasband, W.S.; Eliceiri, K.W. NIH Image to ImageJ: 25 years of image analysis. Nat. Methods 2012, 9, 671-675. [CrossRef]

48. Timmermann, T.; Armijo, G.; Donoso, R.; Seguel, A.; Holuigue, L.; González, B. Paraburkholderia phytofirmans PsJN protects Arabidopsis thaliana against a virulent strain of Pseudomonas syringae through the activation of induced resistance. Mol. Plant Microbe Interact. 2017, 30, 215-230. [CrossRef]

49. Murashige, T.; Skoog, F. A revised medium for rapid growth and bio assays with tobacco tissue cultures. Physiol. Plant. 1962, 15, 473-497. [CrossRef] 
50. Arnon, D.I. Copper enzymes in isolated chloroplasts. Polyphenoloxidase in Beta vulgaris. Plant Physiol. 1949, 24, 1-15. [CrossRef]

51. Lichtenthaler, H.K. Chlorophylls and carotenoids: Pigments of photosynthetic biomembranes. In Methods in Enzymology, 1st ed.; Paker, L., Douce, R., Eds.; Academic Press: New York, NY, USA, 1987; Volume 148, pp. 350-382.

52. Liang, Y.; Urano, D.; Liao, K.-L.; Hedrick, T.L.; Gao, Y.; Jones, A.M. A nondestructive method to estimate the chlorophyll content of Arabidopsis seedlings. Plant Methods 2017, 13, 26. [CrossRef]

53. Yan, S.; Liu, H.; Mohr, T.J.; Jenrette, J.; Chiodini, R.; Zaccardelli, M.; Setubal, J.C.; Vinatzer, B.A. Role of recombination in the evolution of the model plant pathogen Pseudomonas syringae pv. tomato DC3000, a very atypical tomato strain. Appl. Environ. Microbiol. 2008, 74, 3171-3181. [CrossRef]

54. Jeong, D.W.; Kim, H.R.; Han, S.; Jeon, C.O.; Lee, J.H. A proposal to unify two subspecies of Staphylococcus equorum: Staphylococcus equorum subsp. equorum and Staphylococcus equorum subsp. linens. Antonie Van Leeuwenhoek 2013, 104, 1049-1062. [CrossRef]

55. Jha, B.; Gontia, I.; Hartmann, A. The roots of the halophyte Salicornia brachiata are a source of new halotolerant diazotrophic bacteria with plant growth-promoting potential. Plant Soil 2012, 356, 265-277. [CrossRef]

56. Dutta, J.; Thakur, D. Evaluation of multifarious plant growth promoting traits, antagonistic potential and phylogenetic affiliation of rhizobacteria associated with commercial tea plants grown in Darjeeling, India. PLoS ONE 2017, 12, e0182302. [CrossRef] [PubMed]

57. Mora-Ruíz, R.; Font-Verdera, F.; Díaz-Gil, C.; Urdiaín, M.; Rodríguez-Valdecantos, G.; González, B.; Orfila, A.; Rosselló-Móra, R. Moderate halophilic bacteria colonizing the phylloplane of halophytes of the subfamily Salicornioideae (Amaranthaceae). Syst. Appl. Microbiol. 2015, 38, 406-416. [CrossRef] [PubMed]

58. Mora-Ruíz, M.D.R.; Alejandre-Colomo, C.; Ledger, T.; González, B.; Orfila, A.; Rosselló-Móra, R. Non-halophilic endophytes associated with the euhalophyte Arthrocnemum macrostachyum and their plant growth promoting activity potential. FEMS Microbiol. Lett. 2018, 365, fny208. [CrossRef] [PubMed]

59. Jeong, D.W.; Heo, S.; Ryu, S.; Blom, J. Genomic insights into the virulence and salt tolerance of Staphylococcus equorum. Sci. Rep. 2017, 7, 5383. [CrossRef] [PubMed]

60. Mahmood, A.; Turgay, O.C.; Farooq, M.; Hayat, R. Seed biopriming with plant growth promoting rhizobacteria: A review. FEMS Microbiol. Ecol. 2016, 92, fiw112. [CrossRef] [PubMed]

61. Saber, Z.; Pirdashti, H.; Esmaeili, M.; Abbasian, A.; Heidarzadeh, A. Response of wheat growth parameters to co-inoculation of plant growth promoting rhizobacteria (PGPR) and different levels of inorganic nitrogen and phosphorus. World Appl. Sci. J. 2012, 16, 213-219.

62. Sharifi, R. Study of nitrogen rates effects and seed biopriming with PGPR on quantitative and qualitative yield of safflower (Carthamus tinctorius L.). Tech. J. Eng. App. Sci. 2012, 2, 162-166.

63. Newman, K.L.; Chatterjee, S.; Ho, K.A.; Lindow, S.E. Virulence of plant pathogenic bacteria attenuated by degradation of fatty acid cell-to-cell signaling factors. Mol. Plant Microbe Interact. 2008, 21, 326-334. [CrossRef]

64. Chu, Y.Y.; Nega, M.; Wolfle, M.; Plener, L.; Grond, S.; Jung, K.; Gotz, F. A new class of quorum quenching molecules from Staphylococcus species affects communication and growth of gram-negative bacteria. PLoS Pathog. 2013, 9, e1003654. [CrossRef]

65. Molina, L.; Constantinescu, F.; Michel, L.; Reimmann, C.; Duffy, B.; Defago, G. Degradation of pathogen quorum-sensing molecules by soil bacteria: a preventive and curative biological control mechanism. FEMS Microbiol. Ecol. 2003, 45, 71-81. [CrossRef]

66. Garge, S.S.; Nerurkar, A.S. Evaluation of quorum quenching Bacillus spp. for their biocontrol traits against Pectobacterium carotovorum subsp. carotovorum causing soft rot. Biocatal. Agric. Biotechnol. 2017, 9, 48-57. [CrossRef]

67. Ivanov, D.A.; Bernards, M.A. Chlorophyll fluorescence imaging as a tool to monitor the progress of a root pathogen in a perennial plant. Planta 2016, 243, 263-279. [CrossRef] [PubMed]

68. Cen, H.; Weng, H.; Yao, J.; He, M.; Lv, J.; Hua, S.; Li, H.; He, Y. Chlorophyll fluorescence imaging uncovers photosynthetic fingerprint of Citrus Huanglongbing. Front. Plant Sci. 2017, 8, 1509. [CrossRef]

69. Qian, G.-L.; Fan, J.; Chen, D.-F.; Kang, Y.-J.; Han, B.; Hu, B.; Liu, F.-Q. Reducing Pectobacterium virulence by expression of an $\mathrm{N}$-acyl homoserine lactonase gene Plpp-aiiA in Lysobacter enzymogenes strain OH11. Biol. Control 2010, 52, 17-23. [CrossRef] 
70. Li, Q.; Ni, H.; Meng, S.; He, Y.; Yu, Z.; Li, L. Suppressing Erwinia carotovora pathogenicity by projecting N-acyl homoserine lactonase onto the surface of Pseudomonas putida cells. J. Microbiol. Biotechnol. 2011, 21, 1330-1335. [CrossRef]

71. Brazelton, J.N.; Pfeufer, E.E.; Sweat, T.A.; Gardener, B.B.; Coenen, C. 2,4-diacetylphloroglucinol alters plant root development. Mol. Plant Microbe Interact. 2008, 21, 1349-1358. [CrossRef]

(C) 2019 by the authors. Licensee MDPI, Basel, Switzerland. This article is an open access article distributed under the terms and conditions of the Creative Commons Attribution (CC BY) license (http://creativecommons.org/licenses/by/4.0/). 